\title{
Effect of selenium exposure on the freshwater bivalve Corbicula fluminea

\author{
E. Fournier ${ }^{1}$, C. Adam ${ }^{1}$, J.C. Massabuau ${ }^{2}$ and J. Garnier-Laplace ${ }^{1}$ \\ ${ }^{1}$ Laboratoire de Radioécologie et d'Écotoxicologie, Institut de Radioprotection et de Sûreté \\ Nucléaire, DEI/SECRE/LRE, Cadarache, Bât. 186, BP. 3, 13115 St-Paul-lez-Durance \\ Cedex, France \\ ${ }^{2}$ UMR 5805, Laboratoire d'Écophysiologie et Écotoxicologie des Systèmes Aquatiques, \\ Université Bordeaux 1 et CNRS, Place du Dr. Peyneau, 33120 Arcachon, France
}

\begin{abstract}
Selenium is essential for most of living organisms. In normoxic to moderately hypoxic freshwaters, Se exists predominantly in the $(+\mathrm{VI})$ and $(+\mathrm{IV})$ oxidation states as selenate and selenite respectively, whereas in the biota it is incorporated as Se (-II) or Se (0). At low concentrations, it acts against oxidative damages, but it may be toxic at higher levels. In filter feeders, such as the freshwater bivalve Corbicula fluminea, the ventilatory activity is a primary limiting step that controls the water influx and therefore the delivery of contaminants. A number of different parameters such as algal food density or presence of contaminant can influence the ventilation and hence the bioaccumulation potential of the contaminant. We report here a set of short-term experiments performed to study the effects of different forms of dissolved Se (selenite, selenate, selenomethionine) and algal-bound $\mathrm{Se}$ on the ventilatory activity of Corbicula fluminea and to evaluate the Se bioaccumulation. All experiments were performed on a 3-day exposure period after acclimatizing the organisms during a 7-day period to the synthetic water, at a regulated algal density. Both bioaccumulation and ventilatory activity of Se exposed groups, in comparison to these of the reference group, varied greatly according to the form of Se used.
\end{abstract}

\section{INTRODUCTION}

Selenium is a naturally occurring trace element acting as an essential micronutrient for living animal organisms. Typical concentrations in unpolluted freshwaters $(0.2 \mu \mathrm{g} / \mathrm{L})$ may be increased in connection with various anthropogenic sources [1]. It exists in surface waters mainly as the high soluble selenite $\mathrm{Se}(+\mathrm{IV})\left(\mathrm{SeO}_{3}{ }^{2-}\right)$ and as selenate $\mathrm{Se}(+\mathrm{VI})\left(\mathrm{SeO}_{4}{ }^{2-}\right)$. Organic selenides, $\mathrm{Se}(-\mathrm{II})$ (including Se-amino-acids and Se-proteins) are produced by biological reduction of selenite and usually occur at lower concentrations in water than inorganic Se species. However, seleno-amino-acids exhibit a greater biovailability than inorganic species [2-3]. In most of living organisms Se acts against oxidative damages in the form of the glutathione peroxydase (Gpx) but also as other selenoproteins, e.g. selenoprotein $\mathrm{P}$ and thioredoxin reductase [4]. Selenium toxicity can occur due to its chemical analogy with sulphur. Development abnormalities and reproductive failure have been observed in fish after trophic contamination [5].

Bivalves are widely used as bioindicators of aquatic pollution, using their ability to accumulate contaminants, such as trace metals, in their tissues [6-7]. Metals can be accumulated through both direct uptake from the dissolved phase and ingestion from the particulate phase. Various studies have demonstrated that food quantity and quality [8-9] and the presence of waterborne metals such as $\mathrm{Hg}$, Se [10] or U [11] can modify the bivalve's ventilation. Ventilation is the primary limiting step that controls the water influx and therefore, the delivery of contaminants into the branchial cavities. These studies have shown that metal bioavailability is not only linked to the aqueous metal speciation, but also to the bivalve respiratory physiology that is closely dependent on environmental factors. 
The study presented here is part of a wider research program whose aim is to characterize Se bioavailability and effects in C. fluminea, as a function of various physiological and environmental factors. Short-term experiments have been performed to determine the bioavailability and the effect of dissolved and algal-bound $\mathrm{Se}$ on the ventilatory flow rate of the widespread bivalve $C$. fluminea. Three main oxidative states were tested. In a first set of experiments, Se was added into the water as three different chemical forms each corresponding to an oxidation state: the two inorganic compounds $\mathrm{Se}(+\mathrm{VI})$ and $\mathrm{Se}(+\mathrm{IV})$, and the seleno-L-methionine $\mathrm{Se}(-\mathrm{II})$ which is the predominant form of Se organic compounds in tissues of plants and algae [12-13]. In a second set of experiments, Se was added by the trophic route via algae pre-exposed to the three different chemical forms of Se.

\section{MATERIALS AND METHODS}

\subsection{Animals collection and maintenance}

C. fluminea specimens $(0.90 \pm 0.05 \mathrm{~g}$ fw for the whole soft body) were collected manually from river Saint-Seurin-sur l'Isle (France). They were maintained at $20^{\circ} \mathrm{C}$, in a polyvinyl chloride tank filled with dechlorinated tap water over washed quartz sand. Animals were fed daily with a suspension of the unicellular algae Chlamydomonas reinhardtii. Half the volume of water was changed once a week.

\subsection{Physico-chemical parameters}

Experiments were performed in polypropylene beakers $(5 \times 5 \times 8 \mathrm{~cm})$ filled with a synthetic water $\left(\mathrm{Ca}^{2+} 290 \mu \mathrm{M} ; \mathrm{Mg}^{2+} 195 \mu \mathrm{M} ; \mathrm{Na}^{+} 500 \mu \mathrm{M} ; \mathrm{K}^{+} 165 \mu \mathrm{M} ; \mathrm{Cl}^{-} 882 \mu \mathrm{M} ; \mathrm{SO}_{4}{ }^{2-} 100 \mu \mathrm{M} ; \mathrm{NO}_{3}{ }^{-} 500 \mu \mathrm{M}\right.$; $\mathrm{CO}_{3}^{-} 24 \mu \mathrm{M} ; \mathrm{PO}_{4}^{3-} 5 \mu \mathrm{M}, \mathrm{pH} 7.0$ at equilibrium) over washed quartz sand. The experiments were performed at $20.0 \pm 0.5{ }^{\circ} \mathrm{C}$. The $\mathrm{pH}$ was regulated at $7.0 \pm 0.1$ by the addition of $\mathrm{NaOH}$ using a $\mathrm{pH}$-stat. Organisms were maintained under a $14 \mathrm{~h}$ light $-10 \mathrm{~h}$ dark photoperiod. Air was bubbled continuously into the tanks to ensure algal mixing, gas-water equilibration and to keep constant the respiratory status of the bivalves. The ionic composition of the water and the algal cell supply were maintained constant using peristaltic pumps under flow-through conditions. During the experiments, the animals were isolated from external vibrations in the laboratory using an antivibrating bench.

\subsection{Exposure protocol}

The bioavailability of Se via the direct or trophic routes and its effect on the ventilation were studied. These experiments were carried out at 2 different algal densities $\left(1-2 \times 10^{5}\right.$ and 3-4 x $10^{5}$ cells $\left./ \mathrm{mL}\right)$ in order to investigate the impact of food availability on the ventilation. After acclimating organisms ( 5 replicates of one individual per beaker) during a 7-day period to the synthetic water and the selected algal density (acclimation period), animals were either exposed for 3 days to dissolved Se: selenite, selenate or seleno-L-methionine at $50 \mu \mathrm{g} / \mathrm{L}$ or to algal bound Se (algae pre-exposed to $2000 \mu \mathrm{g} / \mathrm{L}$ of selenite; selenate or selenomethionine for $1 \mathrm{hr}$ ). The ventilatory flow rate of each bivalve was also estimated 3 times a day according to the Jorgensen's equation [14]:

$$
\dot{V}_{W}=V \cdot\left[\left(\ln X_{O}-\ln X_{t}\right)-\left(\ln X^{\prime} O^{-\ln X_{t}^{\prime}}\right)\right] /(t \cdot m)
$$

where, $V w$ is the ventilatory flow rate $(\mathrm{mL} / \mathrm{hr} / \mathrm{g} \mathrm{fw}) ; t$ is the test duration $(\mathrm{hr}) ; m$ is the bivalve body mass $(\mathrm{g} \mathrm{fw}) ; V$ is the volume of water in each chamber $(\mathrm{mL}) ; X_{0}, X^{\prime}{ }_{0}$, the algal density at the beginning of the measurement (cells $/ \mathrm{mL}$ ), in the test chamber and the reference one (without any bivalve) respectively; $X_{t}, X^{\prime}$, the algal density at the end of the measurement (cells $/ \mathrm{mL}$ ) in the test chamber and the reference one respectively. 
Based on the ventilatory flow rate determined during the experiment and the corresponding concentration of Se in the water column and/or in the algae, we estimated the total amount of Se that passed through the gills during the 3-day exposure period.

$$
Q=[S e] \cdot \dot{V}_{W} \cdot t
$$

where Q corresponds to the quantity of selenium passing through the animal gills ( $\mu \mathrm{g} / \mathrm{g}$ fw), [Se] is the total selenium concentration in the water column (dissolved and/or algal bound $(\mu \mathrm{g} / \mathrm{L})$ ), $\mathrm{V}_{\mathrm{w}}$ is the ventilatory flow rate $(\mathrm{L} / \mathrm{hr} / \mathrm{g} \mathrm{fw})$ and $\mathrm{t}$ is the duration of the experiment (hr). These calculations were performed on the basis assumption that the bivalves stayed open throughout the exposure phase.

Se quantification in the biological samples and in water was performed using the HG-QFAAS method (Hydride Generation - Quartz Furnace Atomic Absorption Spectrometry) [15].

\section{RESULTS AND DISCUSSION}

\subsection{Effect of selenium on the ventilatory flow rate of $C$. fluminea}

\subsubsection{Direct route}

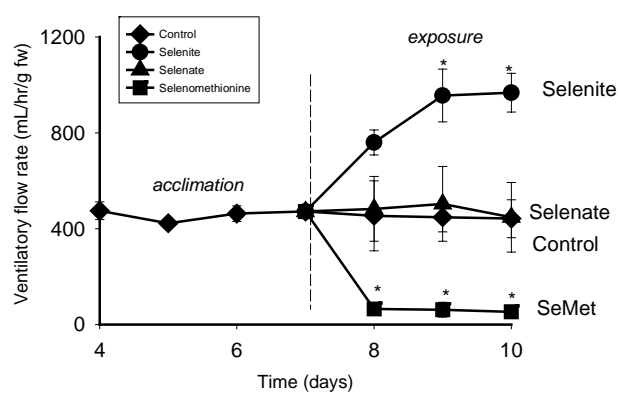

a)

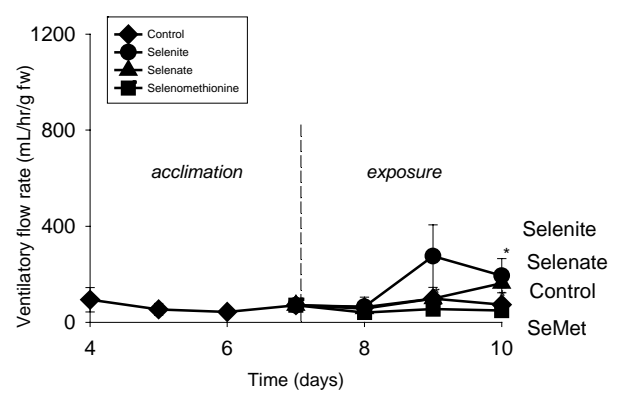

b)

Figure 1. Changes in the ventilatory flow rate $(\mathrm{mL} / \mathrm{hr} / \mathrm{g} \mathrm{fw})$ of $C$. fluminea, as a function of time (days). A 7-day acclimation phase was followed by a 3-day exposure period (3 dissolved selenium forms tested at $50 \mu \mathrm{g} / \mathrm{L}$ ), at two different algal densities: A: $1-2 \times 10^{5}$ cells $/ \mathrm{mL}$ and B: $3-4 \times 10^{5}$ cells $/ \mathrm{mL}$. Asterisks indicate values significantly different from that characterizing the control (Anova, $\mathrm{p} \leq 0.05$ ).

Figure 1 reports the ventilatory flow rate as a function of time. Whatever the conditions, bivalve ventilation reached a steady state during the acclimation period. At the low algal density $\left(1-2 \times 10^{5}\right.$ cells $/ \mathrm{mL}$ ), the control group had a constant high ventilatory flow rate of about $400-500 \mathrm{~mL} / \mathrm{hr} / \mathrm{g} \mathrm{fw}$ during all the experiment, whereas at the high algal density $\left(3-4 \times 10^{5}\right.$ cells $\left./ \mathrm{mL}\right)$, the control group had a constant low ventilatory flow rate of about $50-100 \mathrm{~mL} / \mathrm{hr} / \mathrm{g}$ fw. A low algal density induces a strong ventilation, which allows to compensate the lack of food in the milieu. This pattern has already been reported for C. fluminea by Tran et al. [9]. They observed a stimulation of ventilation for algal densities less than $1-2 \times 10^{5}$ cells $/ \mathrm{mL}$ at $15^{\circ} \mathrm{C}$, whereas, at $25^{\circ} \mathrm{C}$ the stimulation occurred for densities below $4-5 \times 10^{5}$ cells $/ \mathrm{mL}$. At low algal concentration, the addition of $50 \mu \mathrm{g} / \mathrm{L}$ of selenomethionine induced a strong decrease in the ventilatory activity of Corbicula fluminea compared to that of the control group. Changes in the respiratory physiology (ventilation activity and/or valve movement) of C. fluminea have already been shown after addition of other metals, both essential or not essential [11;16-18]. In response to toxic components (such as $\mathrm{Hg}$ or $\mathrm{U}$ ) bivalves often decrease their ventilatory activity as a protective mechanism. As selenomethionine (SeMet) is known to be very 
toxic (96h $\mathrm{LC}_{50}$ of $1.5 \mu \mathrm{g} / \mathrm{L}$ for juvenile amphipods [19]), we suggest the establishment of a protective mechanism expressed by a strong decrease of the ventilation activity of the animals. Remarquably, when bivalves were exposed to dissolved selenite, at $[\mathrm{alg}]=1-2 \times 10^{5}$ cells $/ \mathrm{mL}$, the ventilation increased by a factor of 2 . To our knowledge, only a single study [10] has reported on the effect of selenite on ventilatory activity of a bivalve. The authors used the marine green mussel Perna perna and they tested selenite effect during a 1-hour exposure period instead of 3 days in the present work. They reported a ventilatory inhibition at selenite concentrations ranging from 0 to $300 \mu \mathrm{g} / \mathrm{L}$, stimulation from 300 to $700 \mu \mathrm{g} / \mathrm{L}$ and again an inhibition at higher values. The present results show on the contrary, that selenite induced a strong ventilatory stimulation at $50 \mu \mathrm{g} / \mathrm{L}$. However, any conclusion remains speculative as animal species and experimental conditions were different. For fish, Lemly [20] found that selenium (a mix of dietary selenium $(5.16 \mu \mathrm{g} / \mathrm{g})$ and waterborne selenate:selenite $(4.83 \mu \mathrm{g} / \mathrm{L})$ caused gill damages that decrease respiratory capacity while increasing oxygen consumption. Such a mechanism might explain here the strong stimulation of ventilatory activity following selenite exposure. Finally, selenate did not modify the ventilation of $C$. fluminea, which could indicate that this form was not detected. We must underline that the effect of Se on ventilation is qualitatively similar at high algal density but that statistical differences between groups exposed to SeMet or selenite and control group are only observed at the lower algal density, when ventilatory activity is enhanced.

\subsubsection{Trophic route}

Table 1. Concentration of total selenium in Chlamydomonas reinhardtii ( $\mathrm{pg} / 10^{5}$ cells) pre-exposed to dissolved selenium ( 3 forms tested at $2000 \mu \mathrm{g} / \mathrm{L}$ ), at $\mathrm{pH} 7,20^{\circ} \mathrm{C}$, for $1 \mathrm{hr}$. Values are presented as mean \pm standard error, $\mathrm{n}=3$.

\begin{tabular}{lcc}
\hline & {$[\mathrm{Se}] \mathrm{w} \mu \mathrm{g} / \mathrm{L}$} & $\begin{array}{c}{[\mathrm{Se}] \mathrm{algae}} \\
\mathrm{pg} / 10^{5} \text { cells }\end{array}$ \\
\hline selenomethionine & 2000 & $169 \pm 9$ \\
selenate & 2000 & $26.6 \pm 1.8$ \\
selenite & 2000 & $20.6 \pm 0.6$ \\
\hline
\end{tabular}

Table 1 summarizes the concentration of selenium in algae pre-exposed to selenium. We can observe that each form of selenium has been significantly accumulated in algae during the 1-hour exposure period but at different levels. Indeed, selenomethionine seems to be the most bioavailable form, followed by selenate and selenite.

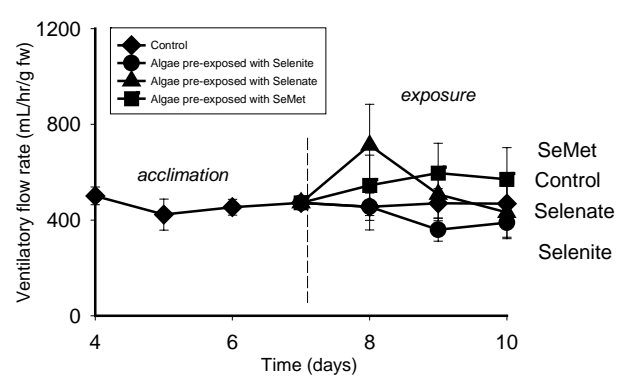

a)

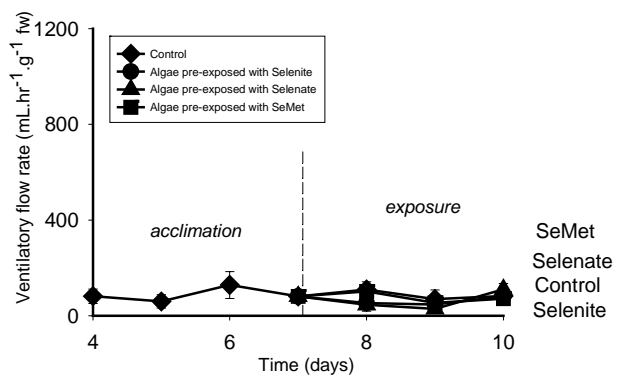

b)

Figure 2. Changes in the ventilatory flow rate $(\mathrm{mL} / \mathrm{hr} / \mathrm{g} \mathrm{fw})$ of C. fluminea, as a function of time (days). A 7-day acclimation phase was followed by a 3-day exposure period to algal-bound selenium (3 selenium forms tested for pre-exposure of algae at $2000 \mu \mathrm{g} / \mathrm{L}$ ), at two different algal densities: A: $1-2 \times 10^{5}$ cells $/ \mathrm{mL}$ and B: $3-4 \times 10^{5}$ cells $/ \mathrm{mL}$. Asterisks indicate values significantly different from that characterizing the control (Anova, $\mathrm{p} \leq 0.05$ ). 
Figure 2 reports the ventilatory flow rate of $C$. fluminea as a function of time, for the two algal densities tested. In reference conditions, the ventilatory flow rates characterizing the control groups are not statistically different from the ones measured in the previous experiment. This illustrates the reproductibility and the strength of the relationship between the ventilatory flow rate and algal concentration, for $C$. fluminea studied in our experimental conditions. It's clear that at the Se concentrations tested, the addition of algal-bound selenium does not induce any statistically significant change in terms of ventilation of $C$. fluminea.

\subsection{Metalloid bioaccumulation}

\subsubsection{Direct route}

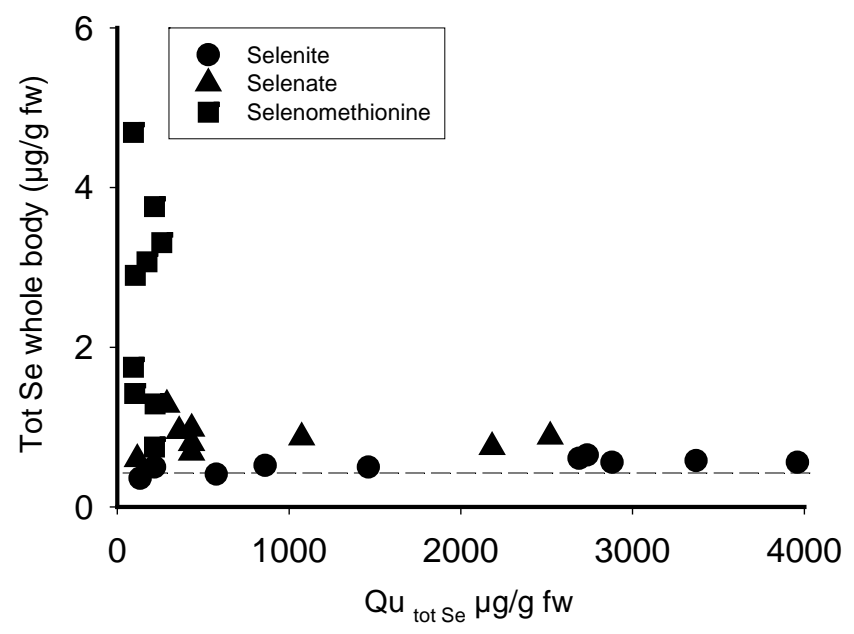

Figure 3. Total Se in the whole body of Corbicula fluminea $(\mu \mathrm{g} / \mathrm{g}$ fw) as a function of total dissolved Se passing through the gills during a 3-day exposure period. Each point corresponds to one bivalve and dotted line to background level.

Total selenium accumulated in the whole body of $C$. fluminea is represented as a function of the quantity of dissolved Se that has been passing through the bivalve gills during the 3-day exposure period. The bioaccumulation rates of the various forms of Se are very different. For example, although a large amount of selenite passed through the gills, because of a strong hyperventilatory response, this form is not bioaccumulated to a high extent. At the opposite, albeit a small quantity of Se has passed though the bivalve (due to the large decrease of ventilation in presence of SeMet), SeMet has been largely accumulated, indicating a high bioavailability of this form. It demonstrated the absence of a relationship between total dissolved Se passing through the gills and bioaccumulation in C. fluminea irrespective of selenium speciation. It evidently underlines the importance of speciation. As regards selenite and selenate, other studies have shown that they can compete with sulphate for uptake, because of their structural similarities [21-22]. It is generally accepted that $\mathrm{SO}_{4}$ is a relatively non-penetrating anion for bivalves [23]. This could explain the poor availability of the Se inorganic forms. On the other hand, in our experiments SeMet seems to be very bioavailable. This is consistent with the literature, which indicates that SeMet is incorporated by an active transport system shared with methionine. 


\subsubsection{Trophic route}

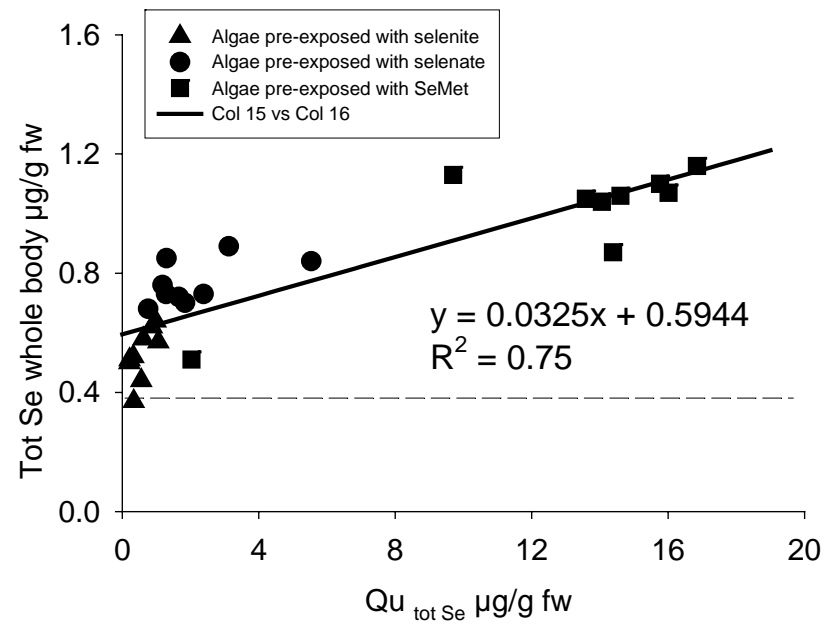

Figure 4. Total Se in whole body of Corbicula fluminea $(\mu \mathrm{g} / \mathrm{g} \mathrm{fw})$ as a function of total algal-bound Se passing through the gills during a 3-day exposure period. Each point corresponds to one bivalve and dotted line to background level.

Total Se accumulated in whole body of $C$. fluminea is represented has a function of the quantity of algal-bound Se passing through the bivalve during the exposure period. It shows that bioaccumulation increases with the total algal-bound Se passing through the gills and potentially eaten by the animals. A linear regression can be applied with a $\mathrm{R}^{2}=0.75$. In this case, ventilation becomes a limitant factor. Two hypotheses can be formulated: once taken up by the algae, each waterborne Se form is transformed and stored in the same chemical form, or, once Se is absorbed in the digestive tract of C. fluminea, all the Se forms are transformed in the same way and so, have got the same bioavailability. The results suggest a transformation of Se inorganic forms into much more bioavailable organic forms.

\section{CONCLUSION}

The present work demonstrates that the ventilation of $C$. fluminea is influenced by algal density and by selenium species. We show that the ventilatory response is closely dependent on the metal form, SeMet inhibits, selenite stimulates and selenate does not influence ventilation. There is no relationship between total dissolved Se passing through the gills and bioaccumulation in $C$. fluminea: which underline the primary importance of speciation. SeMet appears as the more bioavailable form under our experimental conditions. As regard to algal-bound selenium, we demonstrated the existence of a relationship between total algal-bound Se passing through gills and bioaccumulation rates. Thus, as a conclusion, bioaccumulation of Se in bivalves appears as the result of a complex balance between speciation, dissolved and/or algal-bound form and ventilatory activity.

\section{Acknowledgments}

This work is part of the ENVIRHOM program funded by the Institute for Radioprotection and Nuclear Safety. 


\section{References}

[1] Lemly A.D., 2004. Ecotox. Environ. Safe. In press

[2] Kiffney P., Knight A., Arch. Environ. Toxicol. 19 (1990) 488-494.

[3] Wang C., Lovell R.T., Aquaculture. 152 (1997) 223-224.

[4] Arteel G.E., Sies H., Environmental Toxicology and Pharmacology. 10 (2001) 153-158.

[5] Lemly A.D., Ecotox. and Environ. Safe. 10 (1985) 314-338.

[6] Andres S., Baudrimont M., Lapaquellerie Y., Ribeyre F., Maillet N., Latouche C., Boudou A., Environ. Toxicol. Chem. 18 (1999) 2462-2471.

[7] Gunther A.J., Davis J.A., Hardin D.D., Gold J., Bell D., Crick J.R., Scelfo G.M., Sericano J., Stephenson M., Mar. Pollut. Bull. 38 (1999) 170-181.

[8] Foe C., Knight A., Hydrobiologia.133 (1986) 155-164.

[9] Tran D., Boudou A., Massabuau J.C., Environ. Toxicol. Chem. 21 (2002) 327-333.

[10] Watling H.R., Watling R.J., Bull. Environm. Contam. Toxicol. 29 (1982) 651-657.

[11] Tran D., Massabuau J.C., Garnier-Laplace J., 2004. Environ. Toxicol. Chem. 23 (2004) 739-747.

[12] Tinggi U., Toxicol. Lett. 2003 (137) 103-110.

[13] Guo X., Wu L., Ecotox. and Environ. Safe. 39 (1998) 207-214.

[14] Coughlan J., Mar. Biol. 2 (1969) 356-358.

[15] Gleyzes C., Seby F., Lespes G., Potin-Gautier M., Analusis: 25 (1997) 273-278.

[16] Tran D., Ciret P., Ciutat A., Durrieu G., Massabuau J.C., Environ. Toxicol. Chem. 22 (2003a) 914-920.

[17] Tran D., Fournier E., Durrieu G., Massabuau J.C., Aquat. Toxicol. 65 (2003b) 317-327.

[18] Fournier E., Tran D., Denison F., Massabuau J.C., Garnier-Laplace J., Environ. Toxicol. Chem. 23 (2004) 1108-1114.

[19] Hyne R.V., Hogan A.C., Pablo F., Roach A.C., Ecotox. Environ. Safe. 52 (2002) 30-37.

[20] Lemly A.D., Aquat. Toxicol. 27 (1993) 133-158.

[21] Riedel G.F., Sanders J.G., Environ. Toxicol. Chem. (1996) 15: 1577-1583.

[22] Morlon H., Fortin C., Adam C., Garnier-Laplace J. (2003). SETAC Europe 2003, Hambourg.

[23] Dietz TH, Byrne RA., Can. J. Zool. (1999) 77: 331-336. 